\title{
Pengaruh Efektivitas Media Sosial, Daya Tarik, Harga Tiket, dan Fasilitas Pelayanan Wisata Terhadap Keputusan Berkunjung di Curug Goa Jalmo Kabupaten Pasuruan
}

\author{
Tina Rahmadayanti, Kholid Murtadlo \\ Universitas Yudharta Pasuruan \\ tinarahmadayanti98@gmail.com,kholidmurtadlo@yudharta.ac.id
}

\section{Article Info}

\section{Article history:}

Received Nov19th, 2020

Revised Dec12th, 2020

Accepted Dec20th, 2020

\section{Keyword:}

Effectiveness of Social

Media,

Attractiveness,

Ticket Prices,

Tourist Service Facilities,

Visiting Decisions.

\begin{abstract}
The purpose of this study was to determine the effect of social media effectiveness, attractiveness, ticket prices, and tourist service facilities in making someone decide to visit Curug Goa Jalmo, Pasuruan Regency. The samples taken were 133 respondents. Samples taken are visitors to the jalmo cave tour. This research uses quantitative research methods with multiple linear regression analysis. The type of data in this study is primary data. The results of this study indicate that: the effectiveness of social media has no significant effect on visiting decisions, tourist attraction has a significant effect on visitor decisions, ticket prices have a significant effect on visiting decisions, and tourist service facilities have a significant effect on the decision to visit Curug Goa Jalmo, Pasuruan Regency. .

Copyright@ 2020 Program Studi Ekonomi Syariah Universitas Yudharta Pasuruan All rights reserved.
\end{abstract}

DOI: https://doi.org/10.35891/ml.v12i1.2392

\section{Corresponding Author:}

Kholid Murtadlo,

Lecture in University of Yudharta Pasuruan

Email: kholidmurtadlo@yudharta.ac.id 


\section{A. Pendahuluan}

Pariwisata merupakan salah satu sektor industri yang ikut berperan dalam usaha peningkatan pendapatan di Indonesia. Menurut Mulae \& Said, (2019) produk dan jasa pariwisata tidak hanya potensi, tetapi terdapat unsur-unsur lain yang juga menjadi satu kesatuan didalam produk wisata yaitu aksesbilitas, amenitas, dan hospitally.

Pada saat ini berkunjung ke tempat wisata merupakan salah satu gaya hidup yang sedang naik daun untuk memenuhi suatu keinginan dan kebutuhan masyarakat (Fitrian et al., 2017). Kabupaten Pasuruan adalah salah satu daerah yang memiliki banyak potensi wisata serta keberagaman budaya yang menjadi daya tarik tersendiri untuk mengembangkan potensi wisata. Potensi alam yang secara geografis dikelilingi perbukitan dan pegunungan menjanjikan keindahan alam yang masih asri dan bersih. Salah satu wisata yang menyuguhkan keindahan alam air terjun dan goa dalam satu tempat dengan nuansa pedesaanya itu Wisata Curug Goa Jalmo. Wisata Curug Goa Jalmo ini berlokasi di Desa Cendono Kecamatan Purwosari yang tempatnya berjarak kurang lebih 500 meter dari jalan raya.

Daya Tarik yang disuguhkan berupa keindahan alam berupa air terjun yang tidak terlalu tinggi berdampingan dengan Goa Jalmo, kolam renang yang berdekatan dengan lahan persawahan serta paparan pohon pinus yang tinggi. Harga tiket yang ditawarkan pada tempat wisata ini tergolong ramah dikantong karena hanya sebesar Rp.5000-. Tempat wisata ini menyediakan berbagai macam fasilitas pelayanan salah satumnya berupa kedai dengan banyak tempat duduknya diantara pohon pinus yang tinggi, sarana untuk paket outbound anak-anak, serta tempat berfoto yang instagramable. Fasilitas lain yang tersedia ada di wisata ini yaitu gazebo, mushola, dan toilet.

Salah satu faktor yang mempengaruhi wisata ini adalah penerapan efektivitas media sosial, dimana pengaruh strategi pemasaran wisata melalui media sosial berguna untuk mempromosikan Curug Goa Jalmo agar diketahui banyak orang. Curug Goa Jalmo merupakan wisata baru yang masih belum di eksplore secara tuntas dari segi pemasaran wisatanya, daya tarik wisata yang disuguhkan, serta keamanan dan kenyamanan fasilitas pelayanan yang diberikan. Oleh karena itu peneliti memilih Curug Goa Jalmo ini untuk diteliti lebih dalam agar dapat diketahui seberapa besar pengaruh efektivitas media sosial, daya tarik wisata, harga tiket, dan fasilitas pelayanan terhadap keputusan berkunjung.

Objek wisata Curug Goa Jalmo ini menjadi daya tarik yang baru bagi pengunjung khususnya warga Kabupaten Pasuruan untuk menikmati liburan yang menyenangkan dengan melihat air terjun dan goa,serta tempat wisata ini menyuguhkan fasilitas outbound sertam emiliki spot foto yang menarik dan kekinian. Kemudian pengunjung wisata di diperbolehkan untuk membawa bekal dari rumah dan tidak diwajibkan membeli makanan maupun minuman di tempat wisata ini sehingga dapat membuat pengunjung menghemat biaya.

Berdasarkan hukum permintaan semakin rendah harga suatu produk, maka semakin banyak jumlah permintaan atas produk dan sebaliknya (Shinta, 2020). Tidak hanya itu Fasilitas Pelayanan wisata yang menarik dan disesuaikan dengan keinginan 
yang sedang diminati, akan menjadi daya tarik bagi pengunjung untuk berkunjung dan menikmati fasilitas yang tersedia, selain itu kebersihan dan jaminan keamanan dari fasilitas juga menjadi nilai tambah untuk menarik konsumen untuk berkunjung (Zebua, 2018).

Berdasarkan beberapa uraian tersebut wisata Curug Goa Jalmo ini akan mengalami peningkatan apabila pengelola wisata memperhatikan lokasi tempat wisata yang belum bisa diakses dengan menggunakan kendaraan roda empat, serta pelayanan dari pegawai wisata yang perlu ditingkatkan dalam melayani pengunjung wisata.

\section{B. Kajian Teori}

\section{Teori Pemasaran}

Pemasaran adalah kunci utama suatu terbentuknya usaha. Pemasaran adalah kegiatan yang berhubungan dengan arus barang dan usaha jasa antara produsen dan konsumen. Pemasaran adalah salah satu faktor penting untuk menyalurkan dan memenuhi kebutuhan pembeli, baik barupa barang ataupun jasa yang akan diterima konsumen. Tujuan dari pemasaran adalah untuk mempertahankan perusahaan dan memperoleh keuntungan (Nizar, 2017).

Beberapa ahli mengemukakan pendapatnya mengenai teori pemasaran seperti menurut Kotler, (2005); Saladin, (2006) dimana pemasaran adalah suatu system total dari kegiatan bisnis yang dirancang untuk merencanakan, menentukan harga, promosi, dan mendistribusikan barang yang dapat memuaskan keinginan dan mencapai pasar sasaran serta tujuan perusahaan.

Konsep inti pemasaran menurut (Kotler, (2012) meliputi kebutuhan, keinginan, dan permintaan. Pemasaran Pariwisata menurut Kristiutami, (2015) merupakan suatu upaya guna mengidentifikasi kebutuhan dan keinginan wisatawan, serta menawarkan produk wisata sesuai keinginan dan kebutuhan wisatawan.

\section{Efektivitas Media Sosial}

Pengertian efektivitas menurut Sondang, (2009) adalah suatu pemanfaatan sarana prasarana, sumber daya dalam jumlah tertentu yang sebelumnya telah ditetapkan untuk menghasilkan sejumlah barang atau jasa kegiatan yang akan dijalankan oleh seseorang atau suatu perusahaan. Sosial Media atau media sosial merupakan media untuk bersosialisasi dengan satu sama lain dan dilakukan secara online yang memungkinkan manusia untuk saling berinteraksi tanpa dibatasi ruang dan waktu (Arum, 2017). Pengertian media sosial adalah segala bentuk media komunikasi interaktif yang memungkinkan terjadinya interaksi dua arah dan umpan balik (Nizar, 2020)

\section{Daya Tarik Wisata}

Daya tarik adalah kata lain dari suatu objek wisata yang sesuai dengan peraturan Indonesia tahun 2009 . Kata objek wisata sudah tidak relevan lagiuntuk menjelaskan suatu daerah tujuan berwisata maka diganti oleh "DayaTarik". Daya 
Tarik Wisata adalah kegiatan yang menggunakan sesuatu yang memiliki keunikan atau nilai lebih yang dapat berupa, keindahan dari alam maupun budaya yang dimiliki oleh masyarakat yang menjadi sasaran tertentu guna untuk kunjungan wisatawan.

Menurut Karimah \& Hastuti, (2019) Daya tarik wisata adalah sebagai penggerak utama yang memotivasi wisatawan untuk mengunjungi suatu tempat. Daya tarik wisata menurut Puspa, (2019) adalah Daya tarik pariwisata yang bisa berupa kenampakan atau keindahan alam seperti flora dan fauna, bentang alam, tumbuhtumbuhan, dan hasil budidaya manusia seperti museum, monumen, candi, gedung bersejarah, objek wisata yang mencakup manusia dan kebudayaan musik tradisional, tarian dan adat istiadat.

Menurut Wahyudi, (2018) suatu daerah tujuan wisata mempunyai daya tarik disamping harus ada objek dan atraksi wisata, juga harus memiliki 3 syarat daya tarik yaitu something to see, something to do, something to buy.

\section{Harga Tiket}

Dalam sektor pariwisata apabila harga yang ditawarkan tidak sebanding dengan pelayanan dapat berpengaruh kepada minat berkunjung wisatawan. Dimana harga merupakan elemen bauran pemasaran yang dapat menghasilkan pendapatan. Harga adalah nilai suatu barang atau jasa yang dinyatakan dengan uang (Wardhani et al., 2008). Fare atau harga tiket adalah harga yang dibayarkan untuk sebuah tiket. Harga tiket akan berdampak pada ketentuan dan larangan yang melekat pada tiket. Menurut Sulistiyana, (2015) Harga adalah sejumlah yang dibebankan atau dikeluarkan atas sebuah produk dan jasa.

Berdasarkan pendapat dari para ahli dapat disimpulkan bahwa harga adalah unsur penting dalam sebuah perusahaan atau produsen karena harga merupakan alat tukar dan dimana dengan adanya harga maka perusahaan atau produsen akan mendapatkan keuntungan dari penjualan barang ataupun jasa khususnya pada produk pariwisata. Setiap pengunjung wisata akan mempertimbangkan harga tiket dan semua pelayanan wisata dalam pemilihan objek wisata yang akan dikunjungi (Renanita, 2017).

\section{Fasilitas Pelayanan}

Fasilitas adalah sarana untuk melancarkan pelaksaan fungsi yang arti lainnya kemudahan. Fasilitas merupakan hal yang penting dan diperlihatkan dalam sebuah usaha jasa. Dalam usaha jasa penilaian dari konsumen erat kaitannya demi majunya suatu usaha. Menurut (Ilhami et al., 2017) Fasiltas merupakan sarana dan prasarana yang mendukung operasional objek wisata untuk mengakomodasi segala kebutuhan wisatawan, tidak secara langsung mendorong pertumbuhan tetapi berkembang pada saat yang sama atau sesudah atraksi berkembang.

Menurut Wiratini M et al., (2018), fasilitas adalah penyediaan perlengkapanperlengkapan fisik untuk memberi kemudahan kepada konsumen untuk melaksanakan aktivitas-aktivitas sehingga kebutuhan konsumen dapat terpenuhi. 
Dalam konsep Islam pelayanan yang berkenaan dengan tampilan fisik hendaknya tidak menunjukan kemewahan. Fasilitas yang membuat pengunjung merasa nyaman memang penting namun bukan fasilitas yang menonjolkan kemewahan. Kesimpulan yang dapat diambil adalah fasilitas adalah segala sesuatu yang ditempati serta dinikmati oleh para karyawan dan sengaja disediakan untuk dipakai dan dipergunakan serta dinikmati oleh pengunjung yang melaksanakan kegiatan rekreasi (Nizar, 2020).

\section{Keputusan Berkunjung}

Keputusan berkunjung adalah suatu keputusan yang diambil oleh seseorang yang akan melakukan perjalanan ke suatu tempat wisata tertentu untuk berlibur. Keputusan pengunjung untuk memilih objek wisata yang dipilih pada dasarnya merupakan salah satu bentuk pengambilan keputusan (Suratman et al., 2018).

Kristiutami, (2015) menyatakan bahwa keputusan berkunjung wisatawan sama dengan keputusan pembelian. Keputusan berkunjung merupakan sebuah proses dimana seseorang pengunjung melakukan penilaian dan memilih satu alternative yang diperlukan berdasarkan pertimbangan tertentu. Proses pengambilan keputusan sangatlah penting karena dalam melakukan perjalanan wisata seorang pengunjung terlebih dahulu menyiapkan mental, jarak tempuh berapa lama, ke tempat wisata mana dan lain-lain

\section{Metode}

Penelitian ini menggunakan metode kuantitatif. Teknik analisis yang digunakan regresi linier berganda (Ningsih \& Dukalang, 2019). Populasi yang diambil dalam penelitian ini adalah pelanggan yang melakukan kunjungan ke wisata Curug Goa Jalmo. Teknik dalam pengambilan sampel dalam penelitian ini adalah Non-probability Sampling Technique dengan cara pengambilan sampel Purposive sampling (Aisyah, 2016). Besarnya sampel sebanyak 133 responden. Teknik pengumpulan data dalam penelitian ini menggunakan kuisioner (Sevilla, 1993). Berikut ini adalah model kerangka Hipotesis:

\section{Gambar 1: Model kerangka Hipotesis}

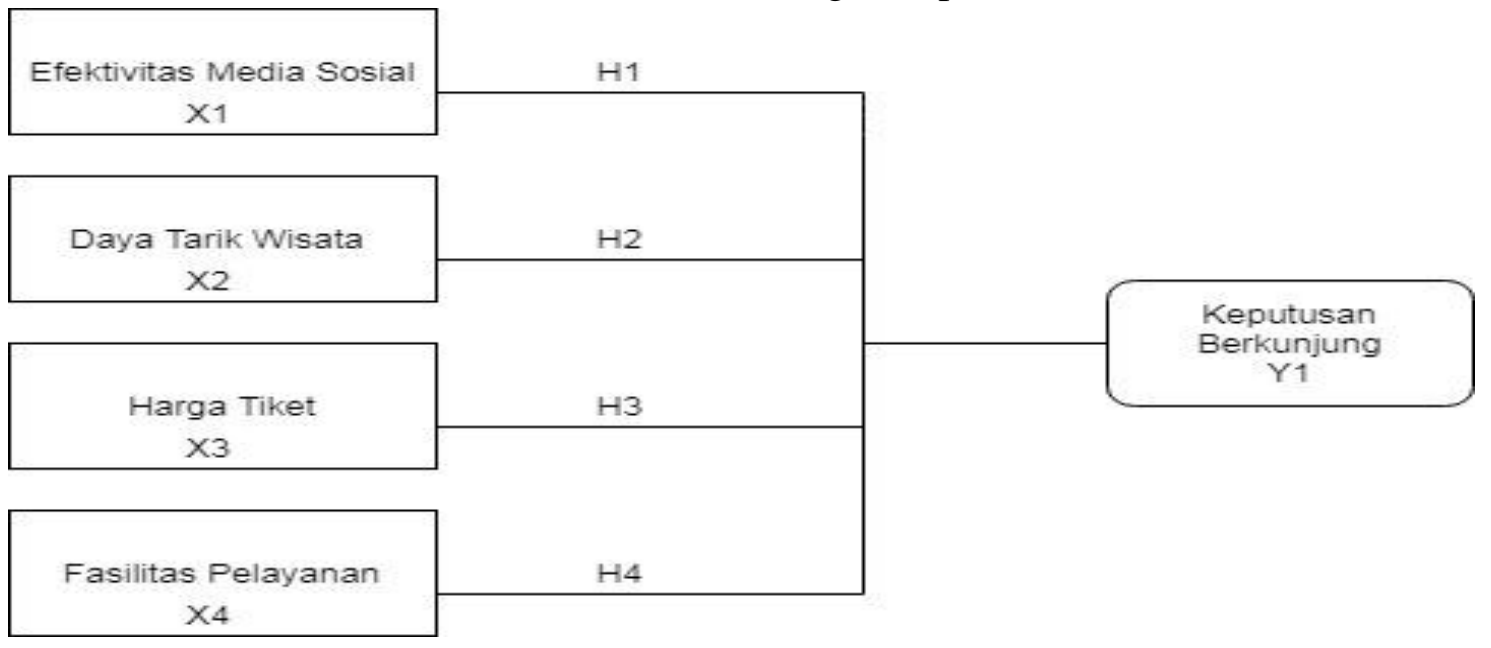

Tina Rahmadayanti, Kholid Murtadlo | 129 
Berdasarkan kerangka hipotesis diatas dapat dijelaskan bahwa:

H1 : Diduga terdapat pengaruh signifikan dari variabel efektivitas media sosial terhadap keputusan berkunjung.

H2 : Diduga terdapat pengaruh signifikan dari variabel daya tarik wisata terhadap keputusan berkunjung.

H3 : Diduga terdapat pengaruh signifikan dari variabel harga tiket wisata terhadap keputusan berkunjung.

H4 : Diduga terdapat pengaruh signifikan dari variabel fasilitas pelayanan wisata terhadap keputusan berkunjung.

\section{Hasil dan Pembahasan}

\section{Analisis Statistik Deskriptif}

Penelitian deskriptif merupakan metode penelitian yang berusaha menggambarkan dan menginterpretasi objek sesuai dengan apa adanya. Data yang dikumpulkan diedit dan ditabulasikan dalam tabel, kemudian data yang diperoleh diinterpretasikan dalam bentuk angka dan persentase.

Diperoleh data persentase pengunjung sebanyak 45\% dari 60 orang pengunjung berusia 17-20 tahun. Persentase 50\% dari 67 orang pengunjung berusia 21-30 tahun. Pada urutan ketiga persentase sebanyak 4,5\% dari 6 pengunjung berusia 31-60 tahun. Maka dapat disimpulkan pengunjung terbanyak berusia 21-30 tahun. diperoleh data persentase pengunjung berdasarkan jenis kelamin. Besar persentase pengunjung laki-laki sebanyak $45 \%$ dari 60 orang pengunjung. Untuk pengunjung perempuan sebanyak $54 \%$ dari 73 orang. Maka dapat disimpulkan bahwa pengunjung terbanyak berjenis kelamin perempuan.

Di ketahui bahwa pengunjung yang memiliki pendapatan kerja kurang dari Rp.500.000 sebanyak 70 orang dengan persentase sebesar 53\%. Data Pengunjung yang memiliki pendapatan sebesar Rp.500.000 - Rp.1.000.000 sebanyak 35 orang dengan persentase sebesar $26 \%$. Data pengunjung yang memiliki pendapatan sebesar Rp.2000.000 - Rp.3.000.000 sebanyak 15 orang dengan persentase sebesar 11\%. Pada data yang terakhir pengunjung yang memiliki pendapatan sebesar Rp.4.000.000 Rp.5.000.000 sebanyak 13 orang dengan persentase sebesar $9,7 \%$.

Berdasarkan pekerjaan pengunjung sebanyak 60 orang adalah pelajar dengan besar persentase $45 \%$. Jenjang pendidikan mahasiswa sebanyak 40 orang dengan besar persentase $30 \%$. Pada pengunjung yang bekerja sebagai karyawan swasta sebanyak 15 orang dengan persentase $11 \%$. Pengunjung yang bekerja sebagai wiraswasta, guru dan TU sebanyak 4 orang dengan besar persentase 3\%. Responden sebanyak 10 orang dengan besar persentase $7,5 \%$ belum bekerja. 


\section{Uji Regresi Berganda}

Model Summary

\begin{tabular}{|c|r|r|r|r|}
\hline Model & R & R Square & \multicolumn{1}{|c|}{$\begin{array}{c}\text { Adjusted R } \\
\text { Square }\end{array}$} & $\begin{array}{c}\text { Std. Error of the } \\
\text { Estimate }\end{array}$ \\
\hline 1 &, $281^{\mathrm{a}}$ &, 079 &, 050 & 1,203 \\
\hline
\end{tabular}

Sumber data diolah,2020

Variabel independen yang diteliti yaitu efektivitas media sosial (X1), Daya tarik(X2), Harga tiket (X3), dan Fasilitas pelayanan wisata (X4) terhadap variabel Keputusan Berkunjung (Y).

Berdasarkan hasil uji koefisien determinasi nilai $\mathrm{R}^{2}$ adalah 0,079 , dapat diketahui nilai Adjusted R Square adalah sebesar 0,50 x $100=50 \%$ yang artinya adalah variabel bebas menjelaskan varian dari variabel terikatnya adalah sebesar $50 \%$ dan terdapat $50 \%$ varian variabel terikat yang di jabarkan oleh faktor lain.

Coefficients $^{\mathrm{a}}$

\begin{tabular}{|c|r|r|r|}
\hline \multirow{2}{*}{ Model } & \multicolumn{2}{|c|}{ Unstandardized Coefficients } & \multicolumn{2}{c|}{$\begin{array}{c}\text { Standardized } \\
\text { Coefficients }\end{array}$} \\
\cline { 2 - 4 } & \multicolumn{2}{|c|}{ B } & \multicolumn{2}{c|}{ Std. Error } & \multicolumn{2}{c|}{ Beta } \\
\hline (Constant) & 8,866 & 1,887 &,- 077 \\
\hline E.M.S &,- 023 &, 026 &, 231 \\
\hline D.T.W &, 215 &, 092 &, 189 \\
\hline H.T &, 237 &, 064 &, 124 \\
\hline F.PEL &, 066 &, 046 & pergan \\
\hline
\end{tabular}

Berdasarkan hasil tersebut dapat diperoleh persamaan regresi linear berganda sebagai berikut:

$\mathrm{Y}=8,688+(-, 077)(\mathrm{X} 1)+, 231(\mathrm{X} 2)+, 189(\mathrm{X} 3)+0,124(\mathrm{X} 4)+\mathrm{e}$

Keterangan

$\mathrm{Y}=$ Keputusan bekunjung

$\mathrm{X} 1=$ Efektivitas media sosial

$\mathrm{X} 2=$ Dayatarik

$\mathrm{X} 3=$ Harga tiket

$\mathrm{X} 4=$ Fasilitas pelayanan

Dari persamaan diatas dapat diketahui:

a. Konstanta sebesar 8,866 yang artinya X1, X2, X3, X4 nilainya adalah 0, maka keputusan berkunjung Y memiliki nilai 8,866

b. Nilai koefisien regresi Efektivitas Media Sosial (B1) mempunyai pengaruh negatif sebesar -,077 menyatakan bahwa jika variabel independen lain dianggap konstan dan Efektivitas Media Sosial mengalami peningkatan sebesar-,077, maka akan dapat menurunkan sebesar -,077 terhadap tingkat keputusan berkunjung di Curug 
Goa Jalmo.

c. Nilai koefisien regresi Daya Tarik (B2) mempunyai pangaruh positif sebesar 0,231, menyatakan bahwa jika variabel independen lain dianggap konstan dan Daya Tarik mengalami kenaikan sebesar 0,231, Maka dapat meningkatkan Keputusan berkunjung sebesar 0,231 terhadap Curug Goa Jalmo .

d. Nilai koefisien regresi Harga Tiket (B3) mempunyai pengaruh positif sebesar 0,189, menyatakan bahwa jika variabel independen lain dianggap konstan dan Harga Tiket mengalami kenaikan sebesar 0,189, Maka dapat meningkat sebesar 0,189 terhadap Keputusan berkunjung Curug Goa Jalmo

e. Nilai koefisien regresi Fasilitas Pelayanan Wisata (B4) mempunyai pengaruh positif sebesar 0,124, menyatakan bahwa jika variabel independen lain dianggap konstan dan Fasilitas pelayanan wisata mengalami kenaikan sebesar 0,124, Maka dapat meningkat sebesar 0,124 terhadap Keputusan berkunjung Curug Goa Jalmo

\section{Hasil Uii Hipotesis}

Berikut adalah hasil dari uji hipotesis :

\begin{tabular}{|l|r|r|}
\hline \multicolumn{1}{|c|}{ Model } & T & \multicolumn{1}{c|}{ Sig. } \\
\hline Constant & 4,698 &, 000 \\
\hline Efektivitas Media Sosial &,- 893 &,- 374 \\
\hline Daya tarik & 2,343 &, 021 \\
\hline Harga Tiket & 3,718 &, 000 \\
\hline Fasilitas Peayanan & 1,426 &, 156 \\
\hline
\end{tabular}

Hasil hipotesis 1 (H1) yang menyatakan Efektivitas Media Sosial tidak berpengaruh signifikan secara parsial terhadap Keputusan Berkunjung. dengan nilai probabilitas (P-Value) -,374 < dari taraf signifikasi 0,05.

Hasil hipotesis $2(\mathrm{H} 2)$ yang menyatakan Daya Tarik Wisata terhadap Keputusan Berkunjung dimana hasilnya menunjukkan berpengaruh signifikan secara parsial dengan nilai probabilitas (P-Value) $0,021<$ taraf signifikasi 0,05

Hasil hipotesis 3 (H3) yang menyatakan harga tiket terhadap Keputusan berkunjung berpengaruh signifikan secara parsial dengan nilai probabilitas (P-Value) $0,000<$ dari taraf signifikansi 0,05 .

Hasil hipotesis 4 (H4) yang menyatakan Fasilitas Pelayanan Wisata terhadap Keputusan berkunjung tidak berpengaruh signifikan secara parsial dengan nilai probabilitas (P-Value) 0,156 > dari taraf signifikansi 0,05. 


\begin{tabular}{|c|c|c|c|c|c|}
\hline \multicolumn{6}{|c|}{ ANOVA $^{\mathrm{a}}$} \\
\hline Model & $\begin{array}{l}\text { Sum of } \\
\text { Squares }\end{array}$ & df & $\begin{array}{l}\text { Mean } \\
\text { Square }\end{array}$ & F & Sig. \\
\hline Regression & 15,920 & 4 & 3,980 & 2,750 &, $000 \mathrm{~b}$ \\
\hline Residual & 185,238 & 128 & 1,447 & & \\
\hline Total & 201,158 & 132 & & & \\
\hline
\end{tabular}

Berdasarkan tabel uji $\mathrm{F}$ dapat dijelaskan bahwa variabel efektivitas media sosial, daya tarik, harga tiket, dan fasilitas pelayanan memiliki nilai f hitung sebesar 2,750 > 2,44 dari $\mathrm{F}$ tabel, maka sapat dikatakan hipotesis ke empat variabel diterima dan berpengaruh simultan terhadap Keputusan berkunjung (Y).

\section{Pembahasan Pengaruh Efektivitas Media sosial terhadap keputusan berkunjung}

Menurut Istiqomah, (2020), efektivitas adalah seberapa baik pekerjaan yang dilakukan, sejauh mana orang menghasilkan keluaran sesuai dengan yang diharapkan. Efektivitas media sosial merupakan salah satu aspek yang penting di dalam sektor pemasaran. Efektivitas media sosial memiliki pengaruh penting dalam bauran pemasaran karena media sosial adalah salah satu media promosi untuk memasarkan tempat wisata.

Efektivitas media sosial yang diterapkan menjadi salah satu metode pemasaran wisata di Curug Goa Jalmo. Dalam memasarkan tempat wisata ini menggunakan media cetak dan ataupun media online dengan memasarkan via aplikasi. Penelitian ini sesuai dengan penelitian terdahulu yang dilakukan oleh (Oktaviani \& Fatchiya, 2019) memiliki hasil penelitian yang menunjukkan bahwa efektivitas media sosial berpengaruh signifikan terhadap keputusan berkunjung. Hal ini hasilnya bertolak belakang dengan hasil penelitian penulis yang mana efektivitas media sosial tidak memiliki pengaruh signifikan terhadap keputusan berkunjung.

\section{Pengaruh Daya Tarik Wisata terhadap keputusan berkunjung}

Pengaruh Daya tarik wisata Menurut (Mulyati \& Masruri, 2019) Daya tarik wisata adalah sebagai penggerak utama yang memotivasi wisatawan untuk mengunjungi suatu tempat. Penggerak di suatu tempat wisata yang utama adalah daya tarik wisata, dimana Daya tarik wisata merupakan salah satu faktor yan menjadikan tempat wisata ini menarik di mata pengunjung. Daya tarik wisata ini menunjukkan keindahan alam yang ditawarkan di objek wisata Curug Goa Jalmo. Daya tarik wisata disini meliputi berbagai macam yang memiliki ketertarikan yang disuguhkan oleh Curug Goa Jalmo seperti air terjun dan Goa Jalmo.

Dalam penelitian ini mendukung penelitian yang dilakukan oleh peneliti (Rheza, 2014) yang menunjukkan variabel daya tarik wisata berpengaruh signifikan terhadap keputusan berkunjung. Hal ini bisa diartikan bahwa daya tarik wisata memiliki peranan penting untuk mempengaruhi keputusan berkunjung. 


\section{Pengaruh Harga tiket terhadap keputusan berkunjung}

Harga tiket adalah salah satu faktor yang mempengaruhi keputusan berkunjung di suatu tempat wisata. Dalam strategi pemasaran harga tiket juga mempengaruhi sesorang untuk memilih berkunjung ke tempat wisata. Harga tiket ini memiliki peran penting karena keuntungan suatu tempat wisata mempengaruhi berjalannya objek wisata tersebut.

Di Curug Goa Jalmo sendiri harga tiket yang ditawarkan sangat terjangkau dan tersedia macam-macam diskon paket outbound. Sesuai dengan penelitian terdahulu Harga tiket menurut Sunarti, (2018) bahwa harga tiket memiliki pengaruh positif dan sinifikan terhadap keputusan berkunjung di Curug Goa Jalmo. Hal ini bisa diartikan bahwa persepsi harga tiket mempunyai peranan penting untuk mempengaruhi keputusan berkunjung.

\section{Pengaruh Fasilitas Pelayanan terhadap keputusan berkunjung}

Menurut Sudarwati et al., (2017) fasilitas merupakan segala sesuatu yang berfungsi memenuhi kebutuhan wisatawan yang tinggal untuk sementara waktu di daerah kunjungan wisata yang dikunjunginya. Fasilitas pelayanan adalah sarana dan prasarana yang disediakan oleh pihak wisata berupa layanan dari karyawan ataupun fasilitas yang tersedia.

Berdasarkan penelitian terdahulu penelitian dari Nizar, (2017), menjelaskan bahwa Fasilitas pelayanan wisata memiliki pengaruh positif terhadap keputusan berkunjung. Sesuai pada objek wisata Curug Goa Jalmo sendiri yang mana fasilitas pelayanan memiliki pengaruh signifikan dan positif terhadap keputusan berkunjungan.

8. Pengaruh Efektivitas media sosial, daya tarik wisata, harga tiket wisata, dan fasilitas pelayanan terhadap keputusan berkunjung.

Hipotesis yang mengatakan bahwa Efektivitas media sosial, daya tarik, harga tiket, dan fasilitas pelayanan secara simultan berpengaruh positif dan signifikan terhadap keputusan berkunjung pada Curug Goa Jalmo. Hal ini bisa dibuktikan dengan hasil uji $\mathrm{F}$ yang memberikan hasil yang signifikan keseluruhan. Efektivitas media sosial, daya tarik, harga tiket dan fasilitas pelayanan memiliki pengaruh signifikan terhadap keputusan berkunjung. Maka dapat disimpulkan bahwa semakin meningkatnya efektivitas media sosial, daya tarik, harga tiket dan fasilitas pelayanan maka akan semakin meningkat keputusan pengunjung untuk mengunjungi objek wisata Curug Goa Jalmo.

\section{E. Kesimpulan}

Berdasarkan analisis data dan pembahasan hasil analisis data penelitian tentang pengaruh efektivitas media sosial, daya tarik wisata, harga tiket dan fasilitas pelayanan terhadap keputusan berkunjung adalah sebagi berikut:

1. Variabel efektivitas media sosial berpengaruh negatif dan tidak signifikan terhadap 
keputusan berkunjung

2. Variabel daya tarik berpengaruh positif dan signifikan secara parsial terhadap keputusan berkunjung

3. Variabel harga tiket berpengaruh positif dan signifikan secara parsial terhadap keputusan berkunjung.

4. Variabel fasilitas pelayanan wisata berpengaruh tidak signifikan secara parsial terhadap keputusan berkunjung. .

5. Variabel efektivitas media sosial, daya tarik, harga tiket, dan fasilitas pelayanan wisata berpengaruh signifikan secara parsial terhadap keputusan berkunjung.

\section{DAFTAR PUSTAKA}

Adriel Jordan Anggono Sunarti. (2018). Pengaruh Harga dan Word of Mouth terhadap Keputusan Berkunjung ( Survei pada Pengunjung Wisata Paralayang, Kota Batu ). Jurnal Administrasi Bisnis (JAB), 61(3), 190-197.

Arum W.P. (2017). Efektivitas Media Sosial Sebagai Media Promosi. Tirtayasa Ekonomika, $12(2), 212-231$.

Fitrian, D., Arifin, R., \& Rachmat, A. (2017). Pengaruh Persepsi Nilai, Persepsi Merek Dan Persepsi Harga Terhadap Minat Berkunjung (Studi Kasus pada Pariwisata Alam Omah Kayu di Batu). E - Jurnal Riset Manajemen Prodi Manajemen Fakultas Ekonomi Unisma Website : Www.fe.unisma.ac.id (email : E.jrm.feunisma@gmail.com)Pengaruh, $51-66$.

Ilhami, M., Nugraha, A., \& Firdaus, H. (2017). Visualisasi Peta Fasilitas Penunjang Wisata Religi Kabupaten Demak Menggunakan Aplikasi Carrymap (Studi Kasus Masjid Agung Demak Dan Makam Kadilangu). Jurnal Geodesi Undip, 6(4), 219-225.

Istiqomah, E. M., \& Istiqomah, I. (2020). Daya Tarik Wisata, Fasilitas Dan Media Sosial Terhadap Keputusan Berkunjung Di Umbul Ponggok Kabupaten Klaten. Jurnal Ilmiah Edunomika, 4(02).

Karimah, S., \& Hastuti, H. (2019). The Development Strategy Of Lake Kelimutu Tourist Attraction In Ende Regency. Geosfera Indonesia, 4(2), 188.

Kotler, P. (2005). Manajemen Pemasaran (1 dan 2). PT. Indeks Kelompok Gramedia.

Kotler, P. (2012). Kotler On Marketing. In Kotler On Marketing (p. 272).

Kristiutami, Y. P. (2015). Pengaruh Bauran Pemasaran Terhadap Keputusan Berkunjung Wisatawan Di Museum Geologi Bandung. Pariwisata, II(2), 77-88.

Muhammad Nizar, A. R. (2020). Tinjauan Wisata Halal Prespektif Maqosidus Syariah Terkait Fatwa Dsn Mui Dsn-Mui No. 08 Tahun 2016. Jurnal Istiqro, 6(1), 95-113.

Mulae, S. O., \& Said, R. M. (2019). Strategi Penilaian Objek Wisata Cengkeh Afo Sebagai Upaya Penguatan Sektor Pariwisata Di Ternate. Humano: Jurnal Penelitian, 10(1), 364.

Mulyati, Y., \& Masruri. (2019). Analisis Faktor-Faktor yang Mempengaruhi Keputusan Berkunjung Wisatawan Domestik Ditinjau dari Perspektif Daya Tarik Destinasi Wisata Kota Bukitinggi. Menara Ilmu LPPM UMSB, XIII(1), 190-205. 
Ningsih, S., \& Dukalang, H. H. (2019). Penerapan Metode Suksesif Interval pada Analsis Regresi Linier Berganda. Jambura Journal of Mathematics, 1(1), 43.

Nizar, M. (2017). Strategi Promosi Dalam Pengembangan Pariwisata Halal Di Taman Wisata Religy Gunung Mujur Karangploso Malang. Al-Ghazwah, 1(1), 87-102.

Oktaviani, W. F., \& Fatchiya, A. (2019). Efektivitas Penggunaan Media Sosial Sebagai Media Promosi Wisata Umbul Ponggok, Kabupaten Klaten. Jurnal Komunikasi Pembangunan, 17(1), 13-27.

Puspa, I. A. T. (2019). Ngaben sebagai Daya Tarik Pariwisata. Pariwisata Budaya: Jurnal Ilmiah Agama Dan Budaya, 4(1), 37.

Renanita, T. (2017). Faktor-Faktor yang Memengaruhi Intensi dan Perilaku Berwisata Masyarakat serta Implikasinya bagi Entrepreneurship Bidang Pariwisata. Jurnal Entrepreneur Dan Entrepreneurship, 4(1, 2), 49-58.

Rheza, A. (2014). Pengaruh Daya Tarik, Fasilitas Dan Aksesibilitas Terhadap Keputusan Wisatawan Asing Berkunjung Kembali Ke Aloita Resort di Kab. KEP. Mentawai. Jurnal Pelangi, 7(1).

S, A. (2016). Metodologi Penelitian: Pendekatan Penelitian. Artikel, 33-40.

Saladin, D. (2006). Manajemen Pemasaran. In Edisi Keempat, Bandung : Linda Karya.

Sevilla, C.G., Ochave, J.A., Punsalan, T. G., \& Regala, B.P. \& Uriarte, G. . (1993). Pengantar Metode Penelitian. UI Press.

Shinta, A. (2020). Manajemen Pemasaran : Manajemen Pemasaran Modern. In Management Pemasaran (Vol. 9, Issue 2).

Sondang, P. S. (2009). Organisasi, kepemimpinan dan Perilaku administrasi. Jakarta: Gunung Agung.

Sudarwati, S., Kustiyah, E., \& Tsani, A. F. (2017). Pengaruh Lokasi, Fasilitas dan Pelayanan Terhadap Keputusan Berkunjung di Taman Satwa Taru Jurug Solo. Jurnal Manajemen Dan Bisnis Indonesia, 4(2), 238-249.

Sulistiyana, R. T, Hamid. D, A. D. F. (2015). Pengaruh Fasilitas Wisata Dan Harga Terhadap Kepuasan Konsumen (Studi Pada Museum Satwa). Jurnal Administrasi Bisnis S1 Universitas Brawijaya, 25(2), 86214.

Suratman, J. P. M., Wilopo, \& Sunarti. (2018). Pengaruh Bauran Pemasaran Jasa Terhadap Keputusan Berkunjung. Jurnal Administrasi Bisnis, 57(2), 12-20.

Wahyudi, I. (2018). Pengembangan Sarana dan Prasarana Daya Tarik Wisata. Ceo Inspire Group, 1.

Wardhani, U. E., Viverawati, \& Mustafa. (2008). Usaha Jasa Pariwisata Jilid 1. In Usaha Jasa Pariwisata Jilid 1.

Wiratini M, N. N. A., Setiawan, N. D., \& Yuliarmi, N. N. (2018). Analisis Faktor-Faktor Yang Mempengaruhi Niat Kunjungan Kembali Wisatawan Pada Daya Tarik Wisata Di Kabupaten Badung. E-Jurnal Ekonomi Dan Bisnis Universitas Udayana, 279.

Zebua, F. N. (2018). Persepsi Wisatawan Terhadap Fasilitas Objek Wisata Dataran Tinggi Dieng Provinsi Jawa Tengah. Jurnal Planologi Unpas, 5(1), 897. 